\title{
To the study of hemipteran assemblages (Insecta: Heteroptera) of aquatic and near-aquatic biotopes of the Meshchera National Park
}

\author{
Irina Yu. Lychkovskaya $\odot$
}

Oka State Natural Biosphere Reserve, Brykin Bor 51, Spassky District, Ryazan Region, 391072 Russia

heteroptera@yandex.ru

Received: 02.07.2020

Revised: 06.12.2020

Accepted: 06.12.2020

Published online: 19.01.2021

DOI: $10.23859 /$ estr-200702

UDC 595.754 (470.314)

Translated by S.V. Nikolaeva

\begin{abstract}
This paper presents the results of a study of hemipteran assemblages in aquatic and semiaquatic biotopes of the Meshchera National Park. The insect fauna, which includes 80 species of 21 families, includes eurytopic species, polyphytophages, and broad oligophytophages, inhabiting biotopes with an herbaceous cover and a wide range of humidity. The fauna is mainly represented by Trans-Palearctic, Superatlantic and Holarctic species. The greatest faunistic similarity is characteristic of hemipteran associations of floodplain meadows with areas of sedge-forb shores $\left(I_{C S}=29.1 \%\right)$ and sedge shores $\left(I_{C S}=21.4 \%\right)$; in addition, the hemipteran assemblages of rivers and ditches are very similar $\left(I_{C S}=14.8 \%\right)$.
\end{abstract}

Keywords: hemipteran associations, Vladimir region, specially protected natural areas, Pol River, Buzha River, Lake Svyatoe.

To cite this article. Lychkovskaya, I.Yu., 2021. To the study of hemipteran assemblages (Insecta: Heteroptera) of aquatic and near-aquatic biotopes of the Meshchera National Park. Ecosystem Transformation 4 (1), 53-60. https://doi.org/10.23859/estr-200702

\section{Introduction}

The territory of the Meshchera National Park, located in the basin of the Oka and Klyazma rivers, contains many bogs and marshy forest areas. The main rivers of the national park are the Buzha River and its left tributary, the Pol River. The rivers of Vladimir Meshchera flow out of large bogs, have low peat banks and a bottom lined with peat; the river valleys merge to a considerable extent with the surrounding swamps, the floodplains are also very swampy. These rivers are characterized by a slow flow and an unstable, often lost channel. In addition, the park contains a significant number of interconnected shallow lakes, most of which are glacial. In particular, these include Lake Svyatoe located in the extreme west of the park, the northernmost in the system of the Lakes Klepikovsky (Presnova and Naumova, 2012). The abundance of water bodies of various origins on the territory of the "Meshchera Park" is of considerable interest from the point of view of the study of invertebrates directly related to the aquatic environment and semiaquatic biotopes.

Professional entomological studies of the hemipteran insects of the Meshchera National Park began only at the beginning of the $21^{\text {st }}$ century. Two specialized papers were published on the hemipteran fauna of the Meshchera Lowland. Nikolaeva (2006) listed some species from this area, and Nikolaeva (2011) published the most complete to date preliminary list of the of terrestrial Hemiptera fauna of the national park (vicinity of Mezinovsky, Chernoe, Dmitrovo) which included 126 species. The "Catalog of invertebrates (Invertebrata: Protozoa et Animalia) of the Vladimir region" (2003) listed 27 hemipteran spe- 
cies, mainly common in Central Russia. Unfortunately, the latter work does not include precise collection localities for the invertebrates, so it is impossible to identify which species were found in the territory of the national park. In addition, two species and one supraspecific taxon of aquatic Hemiptera have been identified in the macrozoobenthos of the Meshchera National Park (Presnova and Naumova, 2012). In the above works, representatives of a number of families were not indicated for the national park: Corixidae, Notonectidae, Naucoridae, Mesoveliidae, Veliidae, Hebridae, Hydrometridae, and Gerridae. In the 2019 field season, the gap in the sampling of aquatic hemipterans and water striders was filled (Lychkovskaya, 2020), with 21 species of Hemiptera, of which 12 were not previously recorded for the Vladimir region, were first identified for the water bodies of the Meshchera National Park. The purpose of this work is to continue the study of the fauna and ecology of hemipterans in aquatic and semi-aquatic biotopes of the Meshchera National Park.

\section{Materials and methods}

The hemipterans were collected in 2019 at 10 sites in the Gus-Khrustalnyi District of the Vladimir Region, within the Meshchera National Park (Fig. 1). The study sites are described below.

1. Buzha River in the vicinity of the village of Urshelsky (Urshelsky district forestry, square no. 100 ), $N 55^{\circ} 40.70^{\prime} \mathrm{E} 40^{\circ} 17.23^{\prime}$. The depth in the river medial zone is $0.3 \mathrm{~m}$, in the river ripal zone it is $0.2 \mathrm{~m}$. The bottom of the river section is covered by silt and plant remains. The river is heavily overgrown with macrophytes: rhizohydrophytes (pondweed Elodea canadensis, yellow water-lily) and hygrohelophytes (sedges, marsh cinquefoil). The riverbank is overgrown with forb-sedge with black alder, willow, and silver birch.

2. Buzha River, $500 \mathrm{~m}$ upstream of the intersection with the Urshelsky - Gus-Khrustalny highway, $\mathrm{N} 55^{\circ} 36.41^{\prime} \mathrm{E} 40^{\circ} 18.88^{\prime}$. Depth in the medial zone $0.5 \mathrm{~m}$, in the ripal zone $-0.3 \mathrm{~m}$. The substrate is muddy with plant remains. The riverbank is gentle, overgrown with hydrohelophytes and hygrohelophytes: sedges, fine-leaved water dropwort, common water-plantain. In the ripal zone, there are neistophytes (hornwort, frogbit), rhizohydrophytes (yellow water-lily, floating pondweed). Along the riverbank there is a floodplain forb meadow with sedges, marsh cinquefoil, loosestrife, and thickets of ash and willow.

3. Buzha River near the village of Yagodino. The following areas and biotopes were examined:

(a) Buzha River before the confluence with the Pol river, N 55 33.90' E 40 17.49'. The depth in the medial zone is $1.5-3.8 \mathrm{~m}$, near the bank $-0.3-1.3 \mathrm{~m}$. The substrate in the ripal and medial zones is sandyclayey. Coastal vegetation is well developed and is represented by sharp sedge, in some places by yellow water-lily. The bank is with a slope of $20-50^{\circ}$, overgrow by forbs, becomes a floodplain meadow with sedges, yarrow, sorrel, veronica, marsh gentian, loosestrife, etc. On the riverbank there are thickets of ash, willow, individual trees of Scots pine, and silver birch. The river is intensely used for recreational and tourist purposes.

(b) Buzha River after the confluence with the Pol

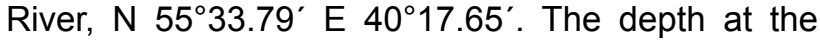
bank is $0.2 \mathrm{~m}$, in the medial zone, up to $0.5 \mathrm{~m}$. The soil of the river is sandy-silty. The bank, with a slope of $10-30^{\circ}$ passes from sedge thickets into a sedgeforb meadow; there are separate trees of pedunculate oak and Scots pine.

4. Buzha River in the vicinity of the village of Tyurvishchi, $N 55^{\circ} 25.00^{\prime} \mathrm{E} 40^{\circ} 12.19^{\prime}$. The depth in the medial zone is $0.3-0.7 \mathrm{~m}$, in the ripal zone it is $0.3 \mathrm{~m}$. The river bottom is silty, clayey-silty, sandy with silt. Near the riverbank, hydrohelophytes and hygrohelophytes grow: spike-rush, grass-rush, arrowhead, burreed, acute sedge. Of the rhizohydrophytes, a yellow water-lily was recorded. In 2019, the river became very shallow; on the floodplain meadow, there was common arrowhead, bur-reed, yellow water-lily, grass rush, frog-bit, sedges. Typical meadow plants include yellow loosestrife, purple loosestrife and cereal forbs.

5. Pol River near the village of Erleks, N 55 ${ }^{\circ} 35.83^{\prime}$ E 40 $23.26^{\prime}$. Depth in the medial zone $0.5 \mathrm{~m}$, in ripal zone $-0.2-0.5 \mathrm{~m}$. The bottom is sandy-silty or silty with plant debris. In the ripal zone, thickets of spikerush, frog-bit, yellow water-lily, common arrowhead, sedge were recorded. The riverbank is variable, gently sloping with willow thickets. The watercourse bank is equipped for recreational purposes and is intensely used for recreation.

6. Pol River near the village of Yagodino, N 55 33.88' E 40¹7.63'. During the survey period, the river became shallow, the depth ranged from 0.2 to $1.2 \mathrm{~m}$. The bottom is sandy-clayey, in places sandy with plant remains. The banks are overgrown with acute sedge. In the ripal zone, water-plantain and spike-rush were recorded.

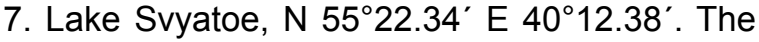
substrate in the littoral is sandy with some silt, in the sublittoral, sapropel. The depth in the sublittoral zone is $1.5 \mathrm{~m}$, in the littoral zone, up to $0.3 \mathrm{~m}$. The following hydrophilic plants are recorded on the sandy bank: spike-rush, sedge, bur-reed, and common reed. The floodplain sedge-forb meadow with yellow loosestrife, purple loosestrife, in places with willows and silver birch.

8. Reclamation ditch in square no. 99 of Mez-

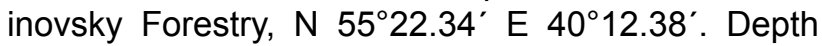
up to $0.7 \mathrm{~m}$. The bottom is muddy with plant remains. Of the macrophytes, duckweed, floating fern, and frog-bit are well developed. The banks are overgrown with sedges. 


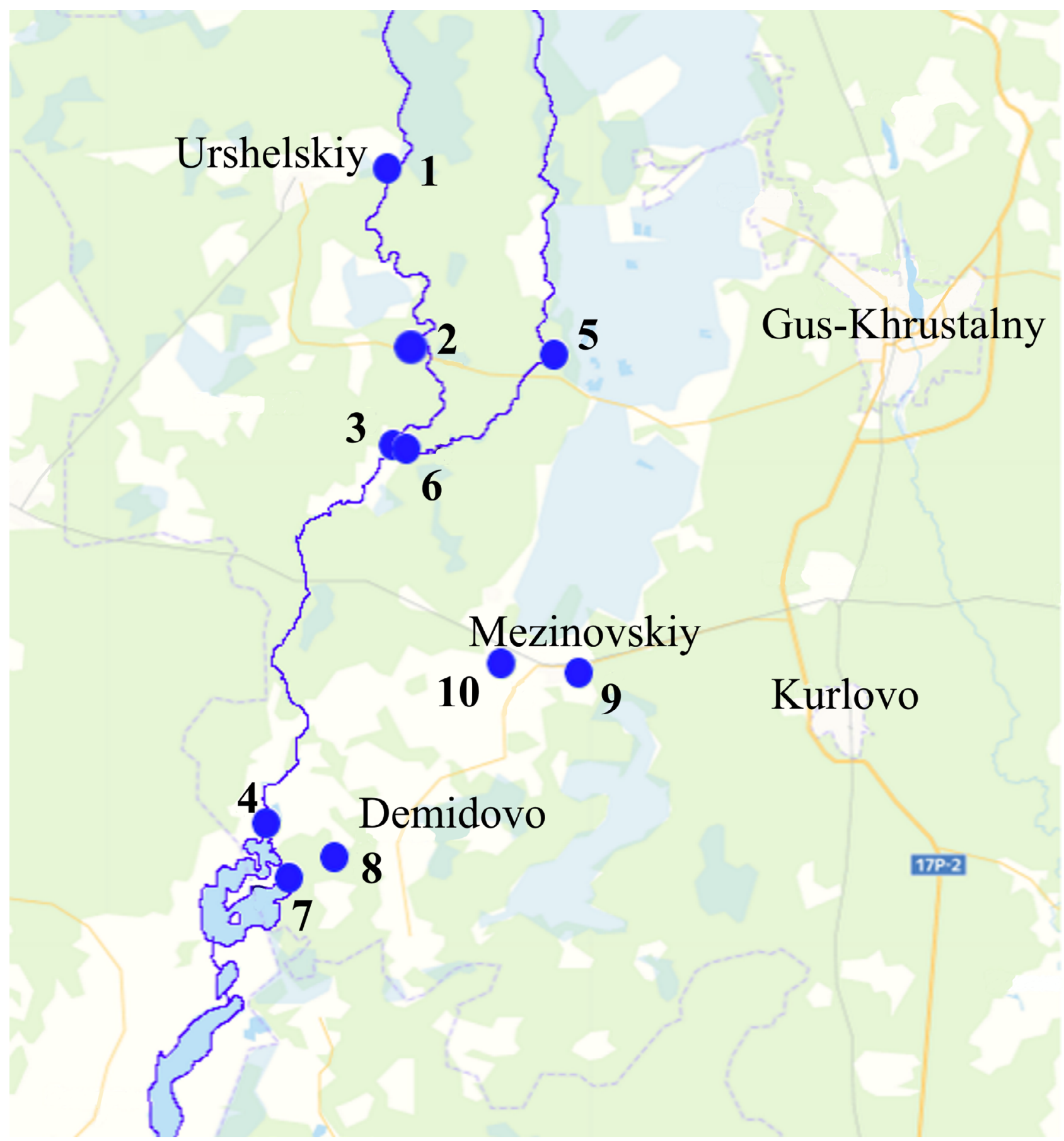

Fig. 1. Scheme of collection points for material on the territory of the Meshchera National Park in 2019 (according to http://russia-karts. ru/karta-vladimirskaja-oblast-podrobnaja-s, modified). 1 - Buzha River, vicinity of the village of Urshelsky; 2 - Buzha River, $500 \mathrm{~m}$ above the intersection with the Urshelsky - Gus-Khrustalnyi highway; 3 - Buzha river near the village of Yagodino; 4 - Buzha River in the vicinity of the village of Tyurvishchi; 5 - Pol River near the village of Erleks; 6 - Pol River, near the village of Yagodino; 7 - Lake Svyatoe; 8 reclamation ditch in square no. 99 of the Mezinovsky Forestry; 9 - drainage ditch of the railway embankment in the vicinity of Mezinovsky; 10 - swampy lowland near the village of Miltsevo. 
9. Drainage ditch of the railway embankment in the vicinity of the village of Mezinovskiy, $\mathrm{N} 55^{\circ} 27.71^{\prime}$ E $40^{\circ} 24.84^{\prime}$. Macrophytes include water knotweed, frog-bit, hornwort, and common reed along the bank.

10. Swampy lowland near the village of Miltsevo, $\mathrm{N} 55^{\circ} 30.13^{\prime} \mathrm{E} 40^{\circ} 26.73^{\prime}$. At the time of collecting the material, it was a dry area with sedges, bulrush, and willows.

According to the data for the city of Vladimir for the period from 2014 to 2019 (Weather..., 2019), in 2019 June was one of the warmest $\left(+18.72^{\circ} \mathrm{C}\right)$ with average long-term indicators of $+16.16^{\circ} \mathrm{C}$, average air humidity in June this year was $60.4 \%$. July and August during the study season turned out to be one of the coldest for the period 2014-2019, the average daily temperature was $+15.38^{\circ} \mathrm{C}$ and $+14.81^{\circ} \mathrm{C}$, respectively. Average values of air humidity were $76.69 \%$ in July and $77.29 \%$ in August.

Insect were trapped from July to September 2019. In semiaquatic biotopes, methods of entomological sweeping of vegetation (hydrohelophytes and hygrohelophytes) and manual collection (from plants and soil) were used. Aquatic organisms were caught by sweeping with a water net in the ripal and littoral zones. Some material was obtained as part of of macrozoobenthos samples using an Ekman-Burge bottom grab with a capture area of $0.01 \mathrm{~m}^{2}$, and material was also collected using a fine-mesh drag. In addition, qualitative studies were carried out using a small water net.

The insects were identified using to the manuals "Keys to insects of the European part of the USSR" (Kerzhner and Yachevsky, 1964) and "Keys to freshwater invertebrates in Russia and adjacent territories" (Kanyukova, 1997); the nomenclature follows the "Catalogue of the Heteroptera the Palaearctic Region" (Aukema and Riger, 1995, 1996, 1999, 2001, 2006).

When assessing the degree of similarity of the faunas of different biotopes, the CzekanowskiSørensen index was used for quantitative data $\left(I_{C S}\right.$, $\%)$. The calculation of the number of insects per unit area during sweeping was carried out according to the formula of M.S. Gilyarov and T.S. Perel (1966). The frequency of occurrence of animal species per total number of samples was calculated according to Kamenev (2002). During quantitative counts in additional samples, there were 4 lifts per 1 combined sample (total - 29 combined samples), when sweeping with a hydrological net for 1 sample -10 strokes (total - 24 samples), when sweeping on ground vegetation per sample - 50 strokes (total - 50 samples). To analyze the dominant structure of the fauna of hemipterans, Renkonen's abundance scale was used (Renkonen, 1938).

\section{Results}

In 2019, 80 species of Hemiptera were recorded in the fauna of the Meshchera National Park. The following families are represented: Nepidae (2 species), Corixidae (5), Naucoridae (1), Notonectidae (2), Pleidae (1), Mesoveliidae (1), Hebridae (1), Hydrometridae (1), Veliidae (2), Gerridae (5), Saldidae (3), Nabidae (4), Anthocoridae (2), Miridae (20), Lygaeidae (9), Rhopalidae (3), Coreidae (1), Plataspidae (1), Acanthosomatidae (1), Scutelleridae (2), and Pentatomidae (13).

Below is a taxonomic list of the hemipterans of the Meshchera National Park; asterisks mark the species recorded for the first time for the Vladimir region. The numbers indicate the collection point (see Fig. 1), the collection methods are indicated in parentheses: entomological sweeping (e), water net sweeping (w), bottom grab samples (b), fine-mesh drag (fd), manual collection $(m)$. Representatives of the families Nabidae, Anthocoridae, Miridae, Lygaeidae, Rhopalidae, Coreidae, Plataspidae, Acanthosomatidae, Scutelleridae, and Pentatomidae were almost all collected by entomological sweeping and were only occasionally collected by hand from plants and soil. It should be noted that occurrences of representatives of Corixidae, Hydrometridae and Gerridae in bottom grab samples are accidental.

\section{List of Heteroptera of the Meshchera National Park}

Family Nepidae Latreille, 1802

Nepa cinerea Linnaeus, $1758-1(w, b), 5(w, b)$.

Ranatra linearis (Linnaeus, 1758) - $4(\mathrm{w}), 7$ (fd).

\section{Family Corixidae Leach, 1815}

Micronecta pusilla (Horváth, 1895) - 2 (w).

Cymatia coleoptrata (Fabricius, 1777) - 1 (w, b), 2 (w, b), 4 (w, b).

Hesperocorixa linnaei (Fieber, 1848) - 1 (w), 2 (b), 4 (b).

H. sahlbergi (Fieber, 1848) - 1 (w), 4 (b), 8 (w), 9 (w). Paracorixa concinna concinna (Fieber, 1848) - 2 (w).

\section{Family Naucoridae Leach, 1815}

Ilyocoris cimicoides cimicoides (Linnaeus, 1758) - 4 (w), $5(w)$.

\section{Family Notonectidae Latreille, 1802}

Notonecta glauca glauca Linnaeus, 1758 - 9 (w). N. lutea Müller, $1776-3(w)$.

\section{Family Pleidae Fieber, 1851}

Plea minutissima minutissima Leach, $1817-4(w)$, 5 (w). 
Family Mesoveliidae Douglas \& Scott 1867

Mesovelia furcata Mulsant \& Rey, $1852-4(w), 5(w)$.

Family Hebridae Amyot \& Serville, 1843

Hebrus pusillus pusillus (Fallén, 1807) - 4 (w).

Family Hydrometridae Billberg, 1820

Hydrometra gracilenta Horváth, $1899-1$ (w), 5 (b).

Family Veliidae Brullé, 1836

Microvelia reticulata (Burmeister, 1835) - 4 (w).

Velia saulii Tamanini, $1947-4$ (w).

\section{Family Gerridae Leach, 1815}

Aquarius paludum paludum (Fabricius, 1794) - 1 (b). Gerris lacustris (Linnaeus, 1758) - 1 (w), 3 (w), 5 (w), 9 (w).

G. thoracicus Schummel, $1832-1$ (b).

G. odontogaster (Zetterstedt, 1828) - 1(w), $3(w)$,

5 (w).

G. lateralis Schummel, $1832-1(w), 5(w)$.

Family Saldidae Amyot \& Serville, 1843

*Saldula arenicola (Scholtz, 1847) - 7 (e).

${ }^{*}$ S. pallipes (Fabricius, 1794) - 7 (e).

S. opacula (Zetterstedt, 1838) - 7 (e).

Family Nabidae A. Costa, 1853

Himacerus apterus (Fabricius, 1798) - 2 .

Nabis brevis brevis Scholtz, $1847-1$.

N. ferus (Linnaeus, 1758) - 9.

N. pseudoferus pseudoferus Remane, 1949 - 1, 10.

Family Anthocoridae Fieber, 1836

${ }^{*}$ Anthocoris nemoralis (Fabricius, 1794) - 4 .

*Orius minutus (Linnaeus, 1758) - 7.

\section{Family Miridae Hahn, 1833}

Deraeocoris ruber (Linnaeus, 1758) - 4 .

Adelphocoris lineolatus (Goeze, 1778) - 7 .

A. ticinensis (Meyer-Dür, 1843) - 2, 4, 7 .

Apolygus limbatus (Fallén, 1807) - 3 .

A. lucorum (Meyer-Dür, 1843) - 6 .

Lygocoris pabulinus (Linnaeus, 1761) - 1, 3, 5 .

L. contaminatus (Fallén, 1807) - 3 .

Lygus gemellatus gemellatus (Herrich-Schaeffer, 1835) $-2,3,5$.

L. pratensis (Linnaeus, 1758) -3 .

L. punctatus Zetterstedt, $1838-1$.

L. rugulipennis Poppius, $1911-1,3$.

L. wagneri Remane, $1955-3,7$.

${ }^{*}$ Polymerus vulneratus (Panzer, 1806) -3.

*Notostira erratica (Linnaeus, 1758) - 3.

Stenodema calcarata (Fallén, 1807) - 3 .
Trigonotylus ruficornis (Geoffroy, 1785) - 3 .

Orthocephalus brevis (Panzer, 1798) - 1 .

*Monosynamma bohemanni (Fallén, 1829) - 3.

Oncolytus punctipes Reuter, 1875 - 1.

Plagiognathus chrysanthemi (Wolff, 1804) - 3.

Family Lygaeidae Schilling, 1829

Nithecus jacobaeae (Schilling, 1829) - 1, 3 .

Nysius ericae ericae (Schilling, 1829) - 3 .

N. helveticus (Herrich-Schaeffer, 1850) - 3.

*Ortholomus punctipennis (Herrich-Schaeffer,

1838) -4 .

Kleidocerys resedae resedae (Panzer, 1797) - 3.

${ }^{*}$ Cymus aurescens Distant, $1883-1$.

C. claviculus (Fallén, 1807) - 1 .

C. glandicolor Hahn, $1832-1$.

Geocoris dispar (Waga, 1839) - 7 .

Family Rhopalidae Amyot \& Serville, 1843

*Brachycarenus tigrinus (Schilling, 1829) - 9.

Rhopalus parumpunctatus Schilling, $1829-4$.

Myrmus miriformis miriformis (Fallén, 1807) - 1, 2, 3,5 .

\section{Family Coreidae Leach, 1815}

Coreus marginatus marginatus (Linnaeus, 1758) - 3 $(e, m)$.

\section{Family Plataspidae Dallas, 1851 \\ Coptosoma scutellatum (Geoffroy, 1785) - 1 .}

\section{Family Acanthosomatidae Signoret, 1864}

Acanthosoma haemorrhoidale haemorrhoidale

(Linnaeus, 1758) $-4,7(\mathrm{~m})$.

\section{Family Scurelleridae Leach, 1815}

Eurygaster maura (Linnaeus, 1758) - 1, 4, 7.

Eu. testudinaria testudinaria (Geoffroy, 1785) - 3, 4,

6, $7(\mathrm{e}, \mathrm{m})$.

\section{Family Pentatomidae Leach, 1815}

Sciocoris cursitans cursitans (Fabricius, 1794) -3 .

S. umbrinus (Wolff, 1804) - 1, 3.

Eurydema oleracea (Linnaeus, 1758) - 4 .

${ }^{*}$ Eysarcoris aeneus (Scopoli, 1763) - 7.

Dolycoris baccarum (Linnaeus, 1758) - 3 .

Carpocoris purpureipennis (De Geer, 1773) - 3 .

Holcostethus strictus vernalis (Wolff, 1804) - 3 .

Palomena prasina (Linnaeus, 1761) - 1, 2, 3.

${ }^{*}$ Rubiconia intermedia (Wolff, 1811) - 3 .

Picromerus bidens (Linnaeus, 1758) - 1 .

Piezodorus lituratus (Fabricius, 1794) - 3 .

Pentatoma rufipes (Linnaeus, 1758) - 3.

Aelia acuminata (Linnaeus, 1758) - 3 . 
In the structure of hemipteran assemblages, no families were identified that predominate in species diversity and density in all areas of the Meshchera National Park surveyed in 2019. It should be noted that due to unfavorable weather conditions accompanying the fieldwork, the hemipteran assemblages of meadow biocenoses in most of the study sites $(1,2$, $4,5,7)$ were minimally represented.

According to the results of collections in 2019, the abundance and occurrence of Hemiptera were low, most terrestrial species were recorded in only $2.0 \%$ of the samples. The small number of chortobionts (average density was 0.8 ind. $/ \mathrm{m}^{2}$, maximum 3.5 ind.$\left./ \mathrm{m}^{2}\right)$, which are usually the largest group, indicates unfavorable weather conditions for all ecological groups of hemipterans in July and August 2019. On sedge-overgrown riverbank slopes, near the water's edge and on floodplain meadows, $N$. jacobaeae (12.0\% of samples), a mesophilic polyphytophage (on Brassicaceae, Asteraceae, Fabaceae, etc.), A. ticinensis (12.0\% of samples) - hygro-mesophilic polyphytophage (legumes and other herbaceous plants), M. miriformis ( $16.0 \%$ of samples) is a mesophilic oligophytophage (on cereals), as well as broad oligophytophages (on grasses, sedges): mesophilic Eu. maura (12.0\% of samples) and hygro-mesophilic Eu. testudinaria ( $10.0 \%$ of samples) were the most common. Of the aquatic hemipterans, $C$. coleoptrata ( $20.7 \%$ of samples) and I. cimicoides $(15.1 \%$ of samples) were most often found in samples. Among water striders, the highest occurrence was observed in G. odontogaster ( $7.6 \%$ of samples) and G. lacustris (5.7\% of samples).

According to the Renkonen abundance scale, the dominant species in the surveyed biotopes are the usual representatives of stagnant and slowly flowing water bodies $G$. lacustris $(9.2 \%$ of the total number of collected hemiptera), C. coleoptrata $(8.9 \%)$, and I. cimicoides $(5.9 \%)$. Representatives of nekton and epineuston $H$. sahlbergi $(4.7 \%), G$. odontogaster (4.5\%), as well as $M$. furcata (epineuston) and epigeobiont $H$. pusillus $(3.1 \%$ each) have subdominant status. In addition, chortobionts, mainly broad oligophytophages: A. ticinensis (4.7\%), Eu. testudinaria $(3.9 \%)$, Eu. maura $(3.6 \%)$, M. miriformis $(2.8 \%)$, L. pabulinus, O. punctipes, N. ericae, C. marginatus, $P$. prasina $(2.0 \%$ each). The proportion of other species does not exceed $1.9 \%$.

In coastal biotopes, among the dominates and subdominants, the main nucleus is mesophilic species (70\%); meso-hygrophilous (20\%) and meso-xerophiles $(10 \%)$ are represented to a lesser extent. The predominance of mesophilic species over hygrophilic species in coastal ecotonic bitotopes was previously indicated by A.M. Kondratyeva and V.B. Golub. They explain this pattern by the fact that ecotonic ecosys- tems, taking into account the high number of species inhabiting them with a wide ecological plasticity, act as reserves that enrich and stabilize adjacent open ecosystems (Kondratyeva and Golub, 2011; Kondratyeva, 2014).

The main life form represented in the studied biotopes are chortobionts (53.8\%), mainly polyphytophages and broad oligophytophages. The next group in terms of the number of species was nekton organisms, accounting for $16.3 \%$ of the number of species. Other life forms accounted for $29.9 \%$.

The fauna of bugs in coastal water biotopes of the Meshchera National Park is represented mainly by Trans-Palaearctic (45.0\%), Superatlantic (23.8\%) and Holarctic species (15.0\%). Species with the Panatlantic type of distribution account for $8.8 \%$, and that for the Western ones $-3.8 \%$. Fewer species were recorded with Western-Pan-Continental, Trans-Eurasian, and Western-Palearctic ranges $-1.3 \%$ each. In the longitudinal direction, boreal-subtropical species prevail $(73.8 \%)$.

When analyzing the faunistic similarity of the hemipteran assemblages of different biotopes, two groups were distinguished: aquatic ecosystems and semi-aquatic biotopes. Among aquatic biotopes, the complexes of rivers with ditches (14.8\%) were distinguished by the greatest faunistic similarity due to representatives of the families Corixidae and Gerridae. For the river and lake complexes, the CzekanowskiSørensen index was $8.7 \%$. In semi-aquatic biotopes, the maximum faunistic similarity was noted in the hemipteran associations of floodplain meadows with areas of sedge-forb banks (29.1\%) (Table 1). Sedge shores with floodplain meadows are slightly less similar $(21.4 \%)$. The rather high level of similarity of the faunas of sedge banks with deciduous trees (18.2\%) is most likely associated with the ecotonic effect: the location of plantings or single deciduous trees close to the water's edge, and, accordingly, next to sedge thickets, makes it possible to collect not only dendrobionts (A. haemorrhoidale, P. rufipes, etc.), but also species of the herbaceous tier (representatives of the families Miridae, Lygaeidae, Pentatomidae).

\section{Conclusions}

In 2019, 80 hemipteran species from 21 families, including 12 species reported for the first time in the Vladimir region, were recorded in the fauna of the Meshchera National Park. In the structure of the hemipteran assemblages in the Meshchera National Park, no families were identified that predominate in species diversity and density in all surveyed sites. The fauna of hemipterans in semiaquatic biotopes is represented mainly by eurytopic species with wide trophic connections, inhabiting biotopes with an herbaceous cover and a wide range of humidity. The 
Table. 1. Degree of faunistic similarity of hemipteran associations in semiaquatic biotopes of the Meshchera National Park $\left(\mathrm{I}_{\mathrm{CS}} \%\right)$. The number of species is given along the central diagonal.

\begin{tabular}{|c|c|c|c|c|c|c|}
\hline Biotope & $\begin{array}{l}\text { Sedge } \\
\text { bank }\end{array}$ & $\begin{array}{l}\text { Sedge-forb } \\
\text { bank }\end{array}$ & $\begin{array}{l}\text { Sandy } \\
\text { bank }\end{array}$ & $\begin{array}{l}\text { Flood } \\
\text { meadow }\end{array}$ & Shrubs & $\begin{array}{l}\text { Deciduous } \\
\text { trees }\end{array}$ \\
\hline Sedge bank & 8 & & & & & \\
\hline $\begin{array}{l}\text { Sedge-forb } \\
\text { bank }\end{array}$ & 16.3 & 33 & & & & \\
\hline Sandy bank & 0 & 0 & 1 & & & \\
\hline Flood meadow & 21.4 & 29.1 & 0 & 16 & & \\
\hline Shrubs & 11.8 & 13.0 & 0 & 8.0 & 7 & \\
\hline $\begin{array}{l}\text { Deciduous } \\
\text { trees }\end{array}$ & 18.2 & 4.4 & 0 & 7.1 & 0 & 10 \\
\hline
\end{tabular}

hemipteran associations of aquatic and semiaquatic biotopes of the Meshchera National Park are mainly represented by Trans-Palearctic $(45.0 \%)$, Superatlantic $(23.8 \%)$ and Holarctic $(15.0 \%)$ species with addition of European fauna species. The hemipteran associations of floodplain meadows with sedge-forb shores $\left(I_{C S}=29.1 \%\right)$ and sedge shores $\left(I_{C S}=21.4 \%\right)$ are characterized by the maximum faunistic similarity. Among the water bodies, the greatest similarity was recorded for the hemipteran assemblages of rivers and ditches $\left(I_{C S}=14.8 \%\right)$.

\section{Acknowledgments}

The author expresses his gratitude to the Deputy Director of the Federal State Budgetary Institution "Oksky Zapovednik" V.P. Ivanchev for organizing field research and providing material collected with a finemesh drag.

\section{ORCID}

Irina Yu. Lychkovskaya (D) 0000-0003-0090-0036

\section{References}

Aukema, B., Riger, C., 1995. Catalogue of the Heteroptera of the Palaearctic Region. Volume 1. Netherlands Entomological Society, Amsterdam, Netherlands, $222 \mathrm{p}$.

Aukema, B., Riger, C., 1996. Catalogue of the Heteroptera of the Palaearctic Region. Volume 2.
Netherlands Entomological Society, Amsterdam, Netherlands, $358 \mathrm{p}$.

Aukema, B., Riger, C., 1999. Catalogue of the Heteroptera of the Palaearctic Region. Volume 3. Netherlands Entomological Society, Amsterdam, Netherlands, $577 \mathrm{p}$.

Aukema, B., Riger, C., 2001. Catalogue of the Heteroptera of the Palaearctic Region. Volume 4. Netherlands Entomological Society, Amsterdam, Netherlands, $346 \mathrm{p}$.

Aukema, B., Riger, C., 2006. Catalogue of the Heteroptera of the Palaearctic Region. Volume 5. Netherlands Entomological Society, Amsterdam, Netherlands, $550 \mathrm{p}$.

Gilyarov, M.S., Perel, T.S., 1966. Izuchenie bespozvonochnykh kak komponenta biogeotsenoza [Study of invertebrates as a component of biogeocenosis]. In: Dylis, N.V. (ed.), Programma i metodika biogeotsenologicheskikh issledovaniy [Program and methodology of biogeocenological research]. Nauka, Moscow, USSR, 163-194. (In Russian).

Kamenev, A.G., 2002. Bioproduktivnost i bioindikaciya malyh vodotokov mezhdurechya Sury i Mokshi. Makrozoobentos [Bioproductivity 
and bioindication of small streams between the Sura and Moksha rivers. Macrozoobenthos]. N.P. Ogarev Mordovia State University, Saransk, Russia, 120 p. (In Russian).

Kanyukova, E.V., 1997. Otryad Poluzhestkokrylye ili klopy. Heteroptera [Order Hemiptera or bugs. Heteroptera]. In: Tzalolikhin, S.Ya. (ed.), Opredelitel presnovodnyh bespozvonochnyh Rossii i sopredelnyh territorij. T. 3. Paukoobraznye. Nizshie nasekomye [Keys to freshwater invertebrates of Russia and adjacent territories. T. 3. Arachnids. Lower insects]. Nauka, Saint-Petersburg, Russia, 266-288. (In Russian).

Katalog bespozvonochnyh zhivotnyh (Invertebrata: Protozoa et Animalia) Vladimirskoj oblasti [Catalog of invertebrates (Invertebrata: Protozoa et Animalia) of the Vladimir region], 2003. Vesyolkin, G.A. (ed.). Vladimirinformekocentr, Vladimir, Russia, 43-45. (In Russian).

Kerzhner, I.M., Yachevskij, T.L., 1964. Otryad Hemiptera (Heteroptera) - poluzhestkokrylye, ili klopy [Order Hemiptera (Heteroptera) - Hemiptera, or bugs]. In: Bej-Bienko, G.Ya. (ed.), Opredelitel nasekomyh evropejskoj chasti USSR. T. 1. Nizshie, drevnekrylye, s nepolnym prevrashcheniem [Key to insects of the Far East of the USSR. Vol. 1. Primitively apterous insects, Palaeoptera, with incomplete metamorphosis]. Nauka, Moscow Leningrad, USSR, 655-845. (In Russian).

Kondratyeva, A.M., 2014. Sostav i struktura gemipterokompleksov okolovodnyh ekotonnyh biotopov srednerusskoj lesostepi [Composition and structure of hemipteran assemblages of semiaquatic ecotone biotopes of the Central Russian forest-steppe]. PhD thesis abstract in Biological Sciences. Voronezh, Russia, 23 p. (In Russian).

Kondratyeva, A.M., Golub, V.B., 2011. K izucheniyu fauny kompleksa poluzhestkokrylyh nasekomyh (Heteroptera) pribrezhnyh uchastkov Lipetskoj oblasti [Study of the hemipteran fauna (Heteroptera) of the coastal areas of the Lipetsk region]. Sbornik dokladov konferentsii "XXV Lyubishchevskie chteniya. Sovremennye problemy evolyucii" [Collection of reports of the conference "XXV Lyubishchev Readings. Modern problems of evolution"). Ulyanovsk, Russia, 333-337. (In Russian).

Lychkovskaya, I.Yu., 2020. Predvaritelnye svedeniya po faune vodnyh poluzhestkokrylyh i vodomerok
(Heteroptera: Nepomorpha, Gerromorpha) nacionalnogo parka "Meshchera" (Vladimirskaya oblast) [Preliminary data on the fauna of aquatic hemipterans and water striders (Heteroptera: Nepomorpha, Gerromorpha) of the Meshchera National Park (Vladimir region)]. Tezisy konferencii "Ekologiya vodnyh bespozvonochnyh" [Theses of the conference "Ecology of aquatic invertebrates"]. Borok, Russia, 53. (In Russian).

Karta Vladimirskoi Oblasti [Map of Vladimir Region], 2020. Web page. URL: http://russia-karts.ru/kartavladimirskaja-oblast-podrobnaja-s- (accessed: 28.04.2020). (In Russian).

Nikolaeva, A.M., 2006. Poluzhestkokokrylye Meshcherskoj niziny [Hemiptera of the Meshchera lowland] (Trudy Okskogo gosudarstvennogo prirodnogo biosfernogo zapovednika. Vyp. 25 [Proceedings of the Oka State Natural Biosphere Reserve. Is. 25]). Golos gubernii, Ryazan, Russia, 231 p. (In Russian).

Nikolaeva, A.M., 2011. Predvaritelnyj spisok vidov nazemnyh poluzhestkokrylyh (Insecta, Heteroptera) nacionalnogo parka Meshchera [Preliminary list of species of terrestrial Hemiptera (Insecta, Netheroptera) of the Meshchera National Park]. Trudy Mordovskogo gosudarstvennogo prirodnogo zapovednika imeni P.G. Smidovicha [Proceedings of P.G. Smidovich Mordovia State Nature Reserve] 9, 115-124. (In Russian).

Presnova, E.V., Naumova, N.N., 2012. Issledovanie makrozoobentosa vodoemov nacionalnogo parka "Meshchera" [Study of macrozoobenthos of water bodies of the Meshchera National Park]. Materialy konferencii "Osobo ohranyaemye prirodnye territorii Vladimirskoj oblasti: sovremennoe sostoyanie $i$ perspektivy razvitiya" [Materials of the conference "Specially protected natural territories of the Vladimir Region: current state and development prospects"]. Gus-Khrustalnyi, Russia, 74-82. (In Russian).

Renkonen, O., 1938. Statistisch-ökologische Untersuchungen über die terrestrische Käferwelt der finnischen Bruchmoore Annales Zoologici Societatis Zoologicae-Botanicae Fennicae "Vanamo" 6 (1), 1-231.

Pogoda v Vladimire v iyune, iyule, avguste 2019 [Weather in Vladimir in June, July, August 2019]. Web page. URL: https://weatherarchive.ru (accessed: 28.04.2020). (In Russian). 